\title{
D-DIMERS, POTENTIAL PREDICTIVE FACTOR OF SURVIVAL IN ACUTE ISCHEMIC STROKE IN PATIENT WITH DIABETES
}

\author{
Nicolae Ovidiu Pop ${ }^{1,2}$, Aurel George Mohan ${ }^{1,2}$, Dana Carmen Zaha², Petru Aurel Babeș² \\ ${ }^{1}$ County Emergency Clinical Hospital Oradea, Romania \\ ${ }^{2}$ Faculty of Medicine and Pharmacy, University of Oradea, Romania \\ Corresponding author: pop_ovidiu212@yahoo.com
}

\begin{abstract}
Determination of plasma level of D-dimers in patient with acute ischemic stroke can be used as a potential predictor of survival and correlated with the degree of disability of the patient. This study shows a correlation between the serum level of D-dimers in the diabetic patients with acute ischemic stroke, which may result that the level of D-dimers could be a good predictor of survival in acute ischemic stroke but not a predictor of disability and prognosis.
\end{abstract}

Keywords: D-dimers, acute ischemic stroke, diabetes, survival.

\begin{abstract}
Determinarea nivelului plasmatic al D-dimerilor la pacientul cu accident vascular cerebral ischemic acut poate fi utilizat ca potențial factor predictor al supraviețuirii și corelat cu gradul de dizabilitate a pacientului.

Acest studiu prezintă o corelație între nivelul seric al D-dimerilor la pacientul diabetic cu accident vascular cerebral ischemic acut, de unde ar putea rezulta faptul că nivelul Ddimerilor ar putea fi un bun predictor de supraviețiire în accidentul vascular cerebral ischemic acut, dar nu și un predictor de dizabilitate și prognostic.
\end{abstract}

Cuvinte cheie: D-dimeri, accident vascular cerebral ischemic acut, diabet zaharat, supraviețuire. 


\section{INTERNAL}

\section{Original papers}

\section{Introduction}

Stroke is one of the leading causes of mortality and disability worldwide ${ }^{(1)}$. Acute ischemic stroke is characterized by disturbance of cerebral blood flow and accounts for approximately $80-85 \%$ of strokes ${ }^{(2)}$.

Diabetes is a clear risk factor for stroke, especially for ischemic stroke. Carbohydrate metabolism disorders have a high prevalence in patients with cerebrovascular disease. People with diabetes are at double risk of developing ischemic stroke compared to nondiabetic patients ${ }^{(3)}$. Low LDL is likely associated with risk of hemorrhagic transformation after acute ischemic stroke ${ }^{(4)}$.

D-dimers represent fibrin degradation products, circulating peptides, formed during the activation of the coagulation process ${ }^{(5)}$. The increased level of D-dimeri signifies an increased tendency for fibrin formation and thrombosis ${ }^{(6)}$. Increased plasma concentration of $D$-dimers has been associated with cerebral venous sinus thrombosis ${ }^{(7)}$, spontaneous cerebral hemorrhage ${ }^{(8)}$.

\section{Objectives}

The aim of our study is to present the importance of the serum level of D-dimers in acute ischemic stroke in the diabetic patient versus the non-diabetic patient, where the hypothesis is whether the level of D-dimers can be considered a survival factor in acute ischemic stroke in the diabetic patient.

\section{Material and method}

This study is of a prospective, observational, longitudinal type conducted within the Oradea County's Emergency Clinical Hospital between 2016-2019. In the study, 340 female and male patients aged 40-90 years were enrolled.

Patients were divided into 2 diabetic and nondiabetic groups, where we analyzed as the main criterion the serum level of $D$-dimers as a survival factor in acute ischemic stroke. The serum level of D-dimers was evaluated in the first 24 hours upon admission to our center, and the examination was performed from plasma, the working method of spectrophotometry, these being analyzed on the Architect 4000 analyzer.

\section{Results}

The serum level of D-dimers in the study group is generally between 100 $\mathrm{ng} / \mathrm{ml}$ and $1500 \mathrm{ng} /$ $\mathrm{ml}$, with an average of $313.5,(95 \% \mathrm{Cl}$ for the median 273.4426 to 372.4591 ). The highest value of the level of D-dimers is $5693 \mathrm{ng} / \mathrm{ml}$, and the smallest is only $120 \mathrm{ng} / \mathrm{ml}$ with an arithmetic mean of $620.3(95 \% \mathrm{Cl}$ for the mean 538.3055 to 702.3298). highly statistically significant $(p<0.0001)$ (Figure 1$)$. Diabetics have significantly higher levels of $d$ - 


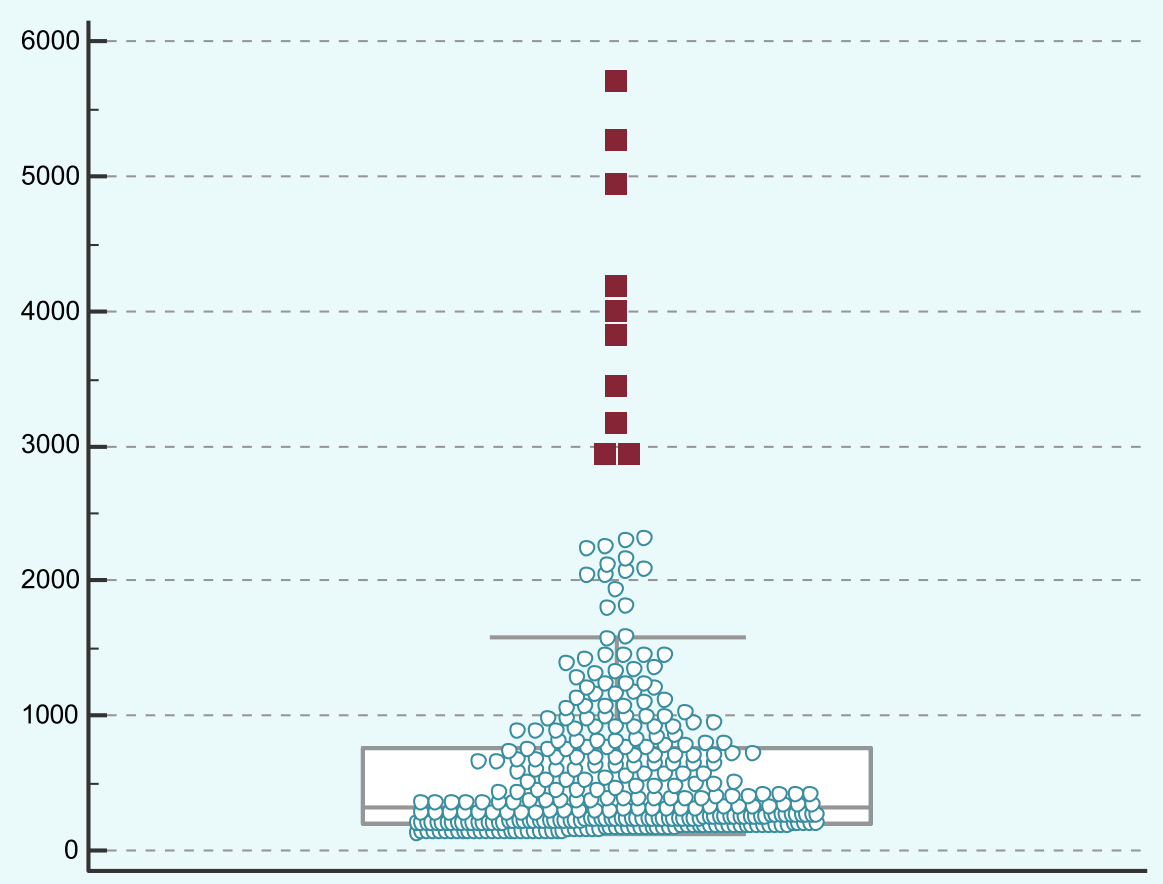

Figure 1. Serum level of D-dimers in the patient with acute ischemic stroke

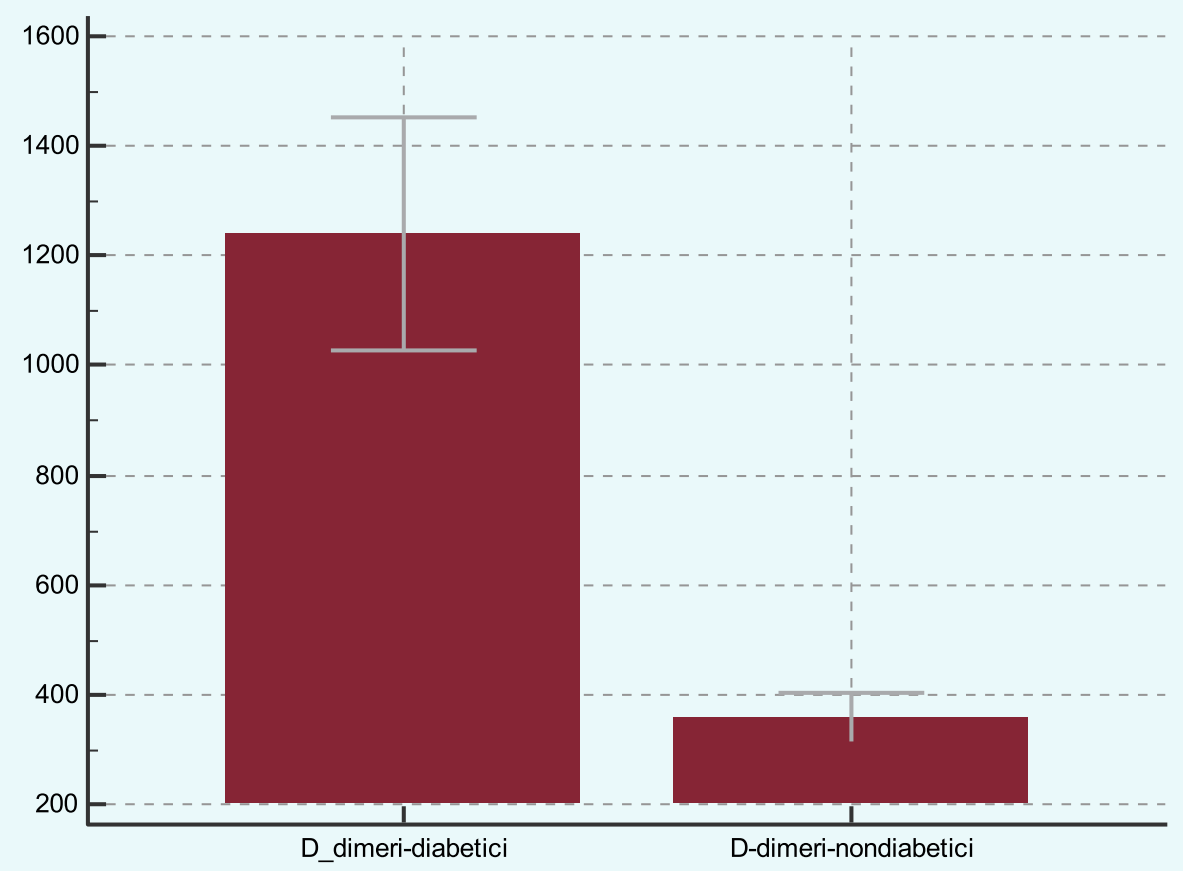

Figure 2. Serum level of D-dimers in diabetic versus non-diabetic patient in acute ischemic stroke 


\section{INTERNAL}

\section{Original papers}

dimers compared to non-diabetic patients (1241 vs 357), (95\% Cl for the mean 1028.3 to $1454)$ for diabetic patients and $(95 \% \mathrm{Cl}$ for the mean 313.6 to 402.1) Non-diabetics, this difference is highly statistically significant. $P$ $<0.0001$ Also the standard deviation of the mean of diabetic patients is much higher than of non-diabetic patients (1078 vs 347), from which we can deduce that the level of $d$ dimers is very variable and generally increased in diabetics who have suffered an acute ischemic stroke (Figure 2 ).

There is a significant statistical and directly proportional correlation between the level of the $D$-dimers and the status from the discharge (RANKIN score). Basically, the higher the level of the D-dimers from the diagnosis, the higher the degree of disability (95\% Confidence interval for $r 0.02468$ to 0.2338 ) $P=0.01$ (Figure 3 ). The ROC analysis of the D-dimer level reveals a cut-off point of $674 \mathrm{ng} / \mathrm{ml}$, with a sensitivity of $46.43 \%$ and a specificity of $74 \%$ ( $95 \% \mathrm{Cl} 0.471$ to 0.580 ). If this level is not reached, we can say that $74 \%$ of patients will not die, thus D-dimers become a predictor of survival and not death and must be taken into account (Figure 4).

\section{Discussions}

In our study there were significantly higher serum levels of D-dimers in the group of diabetic patients compared to the group of non-diabetic patients. Some previous prospective epidemiological studies reveal an association between serum D-dimer levels and stroke ${ }^{(9,10,11)}$.

In some studies the results show that serum Ddimers were associated with stroke severity ${ }^{(12)}$, infarct volume ${ }^{(13,14)}$ and stroke progression ${ }^{(15)}$. The positive serum value of $\mathrm{D}$-dimers in patients with acute ischemic stroke has been indicated by several previous studies confirming this study as well ${ }^{(16,17)}$.

This study presents a correlation between the serum D-dimer level in the diabetic patients with acute ischemic stroke, which may result in the fact that the D-dimer level could be a good predictor of survival in acute ischemic stroke but not a predictor of disability and prognosis. Increased plasma levels of D-dimers upon admission are significantly associated with a poor prognosis of acute ischemic stroke, suggesting that increased plasma levels of Ddimers within the first 72 hours after onset of ischemic stroke are a predictive marker of bad prognosis at 90 days $^{(18)}$.

\section{Conclusions}

The increased plasma level of D-dimers is directly proportional with the degree of disability of the patient with acute ischemic stroke and can be used as a potential predictor of survival in the management of acute ischemic stroke. 


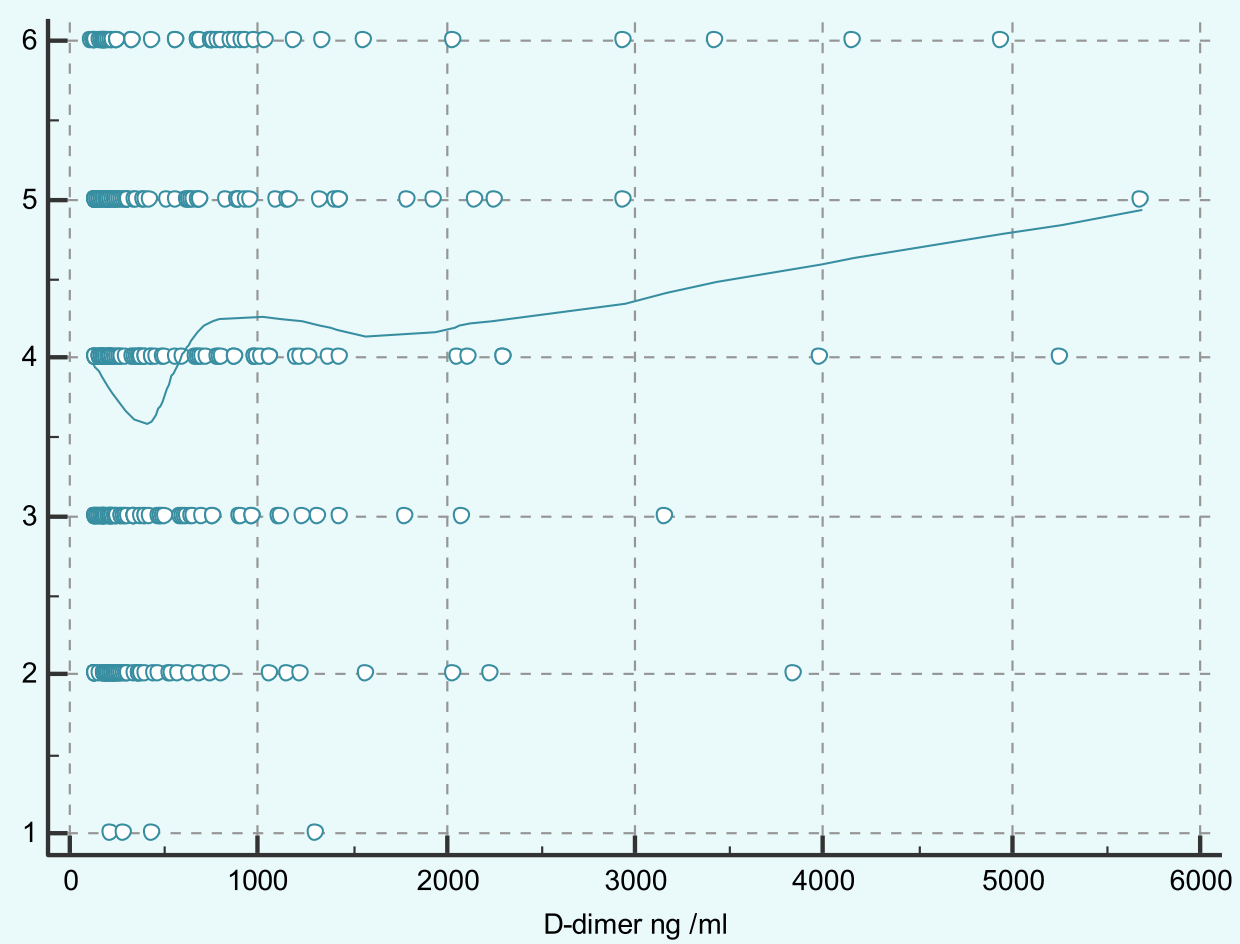

Figure 3. Correlation between the degree of disability objectified by the RANKIN scale from the discharge and the level of $d$-dimers

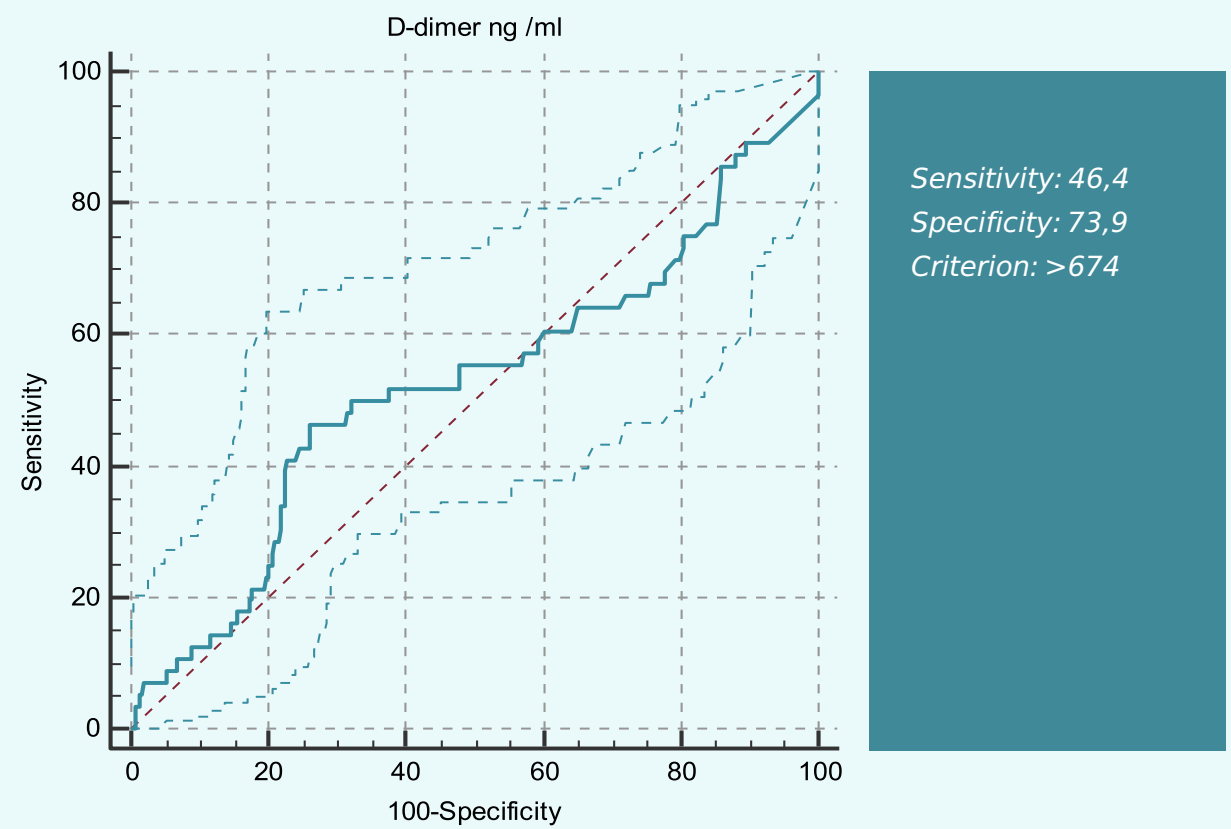

Figure 4. ROC curve of the level of D-dimers 


\section{INTERNAL}

\section{Original papers}

\section{Bibliography}

1. Murray, Christopher JL, and Alan D. Lopez. "Mortality by cause for eight regions of the world: Global Burden of Disease Study." The lancet 349.9061 (1997): 1269-1276.

2. Allen, C. L., \& Bayraktutan, U. (2009). Oxidative stress and its role in the pathogenesis of ischaemic stroke. International journal of stroke, 4(6), 461-470.

3. Luitse, M. J., Biessels, G. J., Rutten, G. E., \& Kappelle, L. J. (2012). Diabetes, hyperglycaemia, and acute ischaemic stroke. The Lancet Neurology, 11(3), 261-271.

4. Pop, N. O., Mekereș, F., Pantiș, C., Voiță, G. F., \& Mekereș, G. M. Influence of LDL and Total Cholesterol Level in Hemorrhagic Transformation of Acute Ischemic Cerebral Stroke in an Elderly Patient.

5. Zakai, N. A., McClure, L. A., Judd, S. E., Kissela, B., Howard, G., Safford, M. M., \& Cushman, M. (2017). Ddimer and the Risk of Stroke and Coronary Heart Disease. Thrombosis and haemostasis, 117(03), 618-624.

6. Adam, S. S., Key, N. S., \& Greenberg, C. S. (2009). Ddimer antigen: current concepts and future prospects. Blood, The Journal of the American Society of Hematology,113(13), 2878-2887.

7. Meng, R., Wang, X., Hussain, M., Dornbos III, D., Meng, L., Liu, Y., ... \& Ding, Y. (2014). Evaluation of plasma Ddimer plus fibrinogen in predicting acute CVST. International Journal of Stroke, 9(2), 166-173.

8. Chiu, C. C., Li, Y. N., Lin, L. J., Hsiao, C. T., Hsiao, K. Y., \& Chen, I. C. (2012). Serum D-dimer as a predictor of mortality in patients with acute spontaneous intracerebral hemorrhage. Journal of Clinical Neuroscience, 19(6), 810-813.

9. Di Castelnuovo, A., Agnoli, C., de Curtis, A., Giurdanella, M. C., Sieri, S., Mattiello, A., ... \& Vineis, P. (2014). Elevated levels of D-dimers increase the risk of ischaemic and haemorrhagic stroke. Thrombosis and haemostasis, 112(11), 941-946.

10. Folsom, A. R., Gottesman, R. F., Appiah, D., Shahar, E., \& Mosley, T. H. (2016). Plasma d-Dimer and incident ischemic stroke and coronary heart disease: the atherosclerosis risk in communities study. Stroke, 47(1),
18-23.

11. Hamatani, Y., Nagai, T., Nakai, M., Nishimura, K., Honda, Y., Nakano, H., ... \& Aiba, T. (2018). Elevated Plasma D-Dimer Level Is Associated With Short-Term Risk of Ischemic Stroke in Patients With Acute Heart Failure. Stroke, 49(7), 1737-1740.

12. Barbieri, A., Giuliani, E., Carone, C., Pederzoli, F., Mascheroni, G., Greco, G., ... \& Genedani, S. (2013). Clinical severity of ischemic stroke and neural damage biomarkers in the acute setting: the STROke MArkers (STROMA) study.

13. Park, Y. W., Koh, E. J., \& Choi, H. Y. (2011). Correlation between serum $D$-dimer level and volume in acute ischemic stroke. Journal of Korean Neurosurgical Society, 50(2), 89 .

14. Zi, W. J., \& Shuai, J. (2014). Plasma D-dimer levels are associated with stroke subtypes and infarction volume in patients with acute ischemic stroke. PloS one, 9(1), e86465.

15. Zang, R. S., Zhang, H., Xu, Y., Zhang, S. M., Liu, X., Wang, J., ... \& Li, H. G. (2016). Serum C-reactive protein, fibrinogen and $D$-dimer in patients with progressive cerebral infarction. Translational neuroscience, 7(1), 8488.

16. Rallidis, L. S., Vikelis, M., Panagiotakos, D. B., Liakos, G. K., Krania, E., \& Kremastinos, D. T. (2008). Usefulness of inflammatory and haemostatic markers to predict short-term risk for death in middle-aged ischaemic stroke patients. Acta Neurologica Scandinavica, 117(6), 415-420.

17. Keller, K., Beule, J., Balzer, J. O., \& Dippold, W. (2018). $D$-Dimer and thrombus burden in acute pulmonary embolism. The American journal of emergency medicine, 36(9), 1613-1618.

18. Yao, T., Tian, B. L., Li, G., Cui, Q., Wang, C. F., Zhang, Q., ... \& XU, L. (2019). Elevated plasma D-dimer levels are associated with short-term poor outcome in patients with acute ischemic stroke: a prospective, observational study. BMC neurology, 19(1), 175. 